\title{
PARTISIPASI DAERAH PENGHASIL(PARTICIPATING INTEREST) DI WILAYAH KERJA (BLOK) MASELA
}

\author{
Junaidi Albab Setiawan \\ Advokat, Pemerhati MIGAS \& Kandidat Doktor \\ Fakultas Hukum Universitas Gadjah Mada \\ Email : albabsetiawan@gmail.com
}

\begin{abstract}
ABSTRAK
Pemerintah daerah melalui BUMD memiliki hak Paricipating Interest sebesar $10 \%$ terhadap kegiatan produksi migas yang dilakukan di wilayahnya. PI adalah hak untuk berpartisipasi dalam kegiatan produksi gas dengan menyetorkan modal dengan kompensasi mendapatkan bagian dari hasil bersih migas yang dihasilkan dan dibatasi dengan jangka waktu kesanggupan selama 60 hari. Pengusahaan produksi hulu Migas diharapkan memberi manfaat kepada daerah melalui keterlibatan BUMD secara langsung dalam pengusahaan sektor hulu migas dan / atau berkembangnya peluang / kegiatan usaha dan penciptaan lapangan kerja dan pendapatan di berbagai kegiatan yang terkait dengan usaha Migas.

Banyak daerah salah paham dan menganggap PI adalah hadiah dan besaran PI sebesar $10 \%$ terlalu kecil dan karenanya menuntut lebih besar. Namun dalam prakteknya kemampuan keuangan daerah sangat terbatas sehingga daerah menghadapi kesulitan untuk dapat membayar keikut sertaan (saham) dalam PI, terlebih lagi jika daerah dilarang untuk melibatkan investor. Larangan melibatkan investor swasta sesungguhnya untuk memastikan bahwa PI tersebut ditujukan khusus untuk kesejahteraan masyarakat daerah penghasil. Keterlibatkan investor swasta ditengarai juga menimbulkan akses pada timbulnya KKN dikalangan tokoh dan pimpinan daerah.

Participating Interest (PI) yang menjadi hak daerah harus dipastikan dimanfaatkan oleh daerah melalui BUMD yang sepenuhnya dimiliki oleh Daerah. Untuk itu, perlu disusun aturan perundangan yang mengatur partisipasi BUMD pada pengusahaan sektor hulu Migas, termasuk di dalamnya kewajiban kerjasama antara BUMD dengan Pertamina atau lembaga keuangan milik negara, tanpa membebani BUMD dengan mengeluarkan biaya investasi dan risiko kerugian usaha. Banyak daerah diliputi kesalahah pahaman dengan anggapan PI sebagai hak tanpa kewajiban menyetorkan dana keikut sertaan.
\end{abstract}

\section{Kata kunci : Participating Interest, Pemerintah daerah, Migas}

\section{ABSTRACT}

The local government through local enterprises have the right Paricipating Interest of $10 \%$ of the oil and gas production activities conducted on its territory. PI is the right to participate in the activities of production of gas by depositing the compensation capital gain portion of the net proceeds of oil and gas produced and is restricted to a period of readiness for 60 days. The utilization of upstream oil and gas production is expected to provide benefits to the region through direct involvement in local enterprises upstream oil and gas exploitation and / or development 
opportunities / business activities and the creation of jobs and income in various activities related to oil and gas business.

Many areas misunderstand and assume PI PI is a gift and the amount of $10 \%$ is too small, and therefore demand is greater. However, in practice very limited fiscal capacity so that regions face difficulties to be able to pay participation (share) in PI, especially if the area is prohibited to engage investors. Prohibition involve private investors in fact to ensure that the PI intended specifically for public welfare producing region. Some allegedly considered private investors also cause access to the incidence of corruption among leaders and regional leaders.

Participating Interest (PI) that is rightfully area must be ensured through the area utilized by enterprises that are wholly owned by the Region. For that, is necessary to develop laws and regulations that govern the participation of enterprises in the exploitation of oil and gas upstream sector, including the obligation of cooperation between enterprises by Pertamina or state-owned financial institution, without burdening enterprises with the cost and risk of loss of business investment. Many areas covered any troubleshooting unfamiliarity with the presumption PI as a right without an obligation to fund participation.

\section{Keywords: Participating Interest, local government, oil and gas}

Pendahuluan

Participating Interests Dalam Kegiatan Usaha Hulu Migas

Beberapa wilayah kerja (wilayah kerja) minyak bumi dan gas bumi (migas) Indonesia pada saat ini banyak yang akan mulai berproduksi dan sebagian akan berakhir masa kontrak pengelolaannya. Dengan berakhirnya masa kontrak maka wilayah kerja tersebut wajib dikembalikan kepada negara dan jika wilayah kerja tersebut masih berpotensi menghasilkan migas maka akan dianggap sebagai wilayah kerja baru. Terhadap wilayah kerja baru atupun wilayah kerja yang dianggap baru tersebut, pemerintah perlu mempersiapkan berbagai skema pangelolaan.

Berkaitan dengan pengalihan kontrak migas yang habis masa berlakunya, Peraturan Pemerintah Nomor 35 Tahun 2004 tentang kegiatan usaha hulu minyak dan gas bumi yang selanjutnya disebut PP No.35/2004, memberikan privilege kepada Pertamina untuk mengajukan penawaran untuk mengusahakan wilayah kerja yang bersangkutan. Selain kepada Pertamina, peralihan kontrak migas juga membuka kesempatan bagi Badan Usaha Milik Daerah (BUMD) untuk berpartisipasi dalam pengusahaan sumber daya migas yang ada di daerahnya. PP No. 35/2004 mengatur kewajiban kontraktor migas untuk menawarkan participating interest (selanjutnya disebut PI) sebesar 10\% kepada BUMD.

Pada saat berakhinya masa pengelolaan wilayah kerja, maka wilayah kerja kembali dikuasai oleh negara. Maka tidak satupun pihak yang berhak kecuali negara dan pengelolaan selanjutnya akan dilakukan oleh pengelola baru sama sekali atau gabungan pengelola lama dan pengelola baru atau pengelola lama yang diberi perpanjangan waktu, yang ditunjuk oleh negara. Pertanyaan yang muncul adalah, dalam kondisi seperti itu dimanakah 
posisi daerah penghasil? Bagaimanakah perundang-undangan di bidang migas mengatur tentang hak partisipasi atau Participating Interest (PI) kepada daerah penghasil melalui Badan Usaha Milik Daerah (BUMD)?

Selama ini daerah-daerah yang wilayahnya meliputi wilayah kerjawilayah kerja migas kurang mendapatkan perhatian yang semestinya. Padahal daerah tersebut adalah daerah yang paling terkena dampak. Setidaknya kekayaan alam yang ada di dalam wilayahnya telah berkurang akibat kegiatan ekploitasi (produksi) usaha hulu migas. Menurut Pasal 5 Undang-Undang Nomor 22 Tahun 2001 tentang Minyak dan Gas Bumi, kegiatan usaha hulu migas adalah kegiatan usaha yang mencakup eksplorasi dan eksploitasi. Ekploitasi migas yang dilakukan secara terus menerus mengakibatkan cadangan yang tersimpan di perut bumi terutama yang berlokasi di daerah penghasil semakin menipis (Jurnal Dunia Ekuin dan Perbankan). Akibatnya daerah penghasil pelan tapi pasti kehilangan cadangan sumber daya alam migas yang terkandung di dalam perut bumi di dalam wilayahnya.

Dalam jangka panjang perlu dipertimbangkan untuk menata kembali skema penyelesaian dari pembagian pendapatan sektor hulu migas yang menempatkan daerah penghasil dengan segala kedudukan dan situasinya sebagai faktor penting, sehingga daerah penghasil dapat memperoleh pendapatan yang lebih pasti dan adil. Hal ini karena daerahlah yang memfasilitasi berbagai kebutuhan terkait eksploitasi, baik dari kebutuhan administratif, keamanan, serta kebutuhan fisik dan material yang meliputi pergudangan peralatan, pengolahan, penampungan hasil dan kebutuhan air dan suplai makanan dan terminal transit. Dari berbagai kegiatan tersebut daerahlah yang pertama kali akan terpapar risiko kerusakan sosial dan pencemaran lingkungan (Deny Hidayati, 2005). Namun ironisnya banyak daerah penghasil justru menjadi potret kesenjangan ekonomi yang menggambarkan dengan jelas siapa yang mendapat manfaat dan siapa yang terabaikan (Tim Komnas Ham). Dengan segala risiko yang dihadapinya, daerah penghasil seharusnya menjadi pihak yang pertama-tama menikmati berkah berupa kemajuan dan kesejahteraan akibat eksploitasi sumber energi di wilayahnya. Maka sangatlah tidak adil jika daerah penghasil dan masyarakatnya tidak mendapatkan prioritas untuk menikmati hasil sumber daya alam migas yang diambil di wilayahnya (Emil Salim, 2000). Selain itu para pelaku harus memberikan perhatikan khusus karena merekalah yang memiliki dan menguasai lahan. Tanpa dibukakan pintu oleh daerah, kegiatan eksplorasi dan eksploitasi tidak mungkin dilakukan.

Kontrak kerjasama usaha hulu migas adalah kontrak jangka panjang. Dahulu ketika pertama kali kontrak ekplorasi dan eksploitasai dibuat, di Indonesia belum dikenal istilah Participating Interest (PI), karenaPI baru diperkenalkan pada tahun 2004, sebagai buah dari adanya ajaran otonomi daerah yang dibawa oleh gerakan reformasi. PI sesungguhnya adalah buah dari desentralisasi dan otonomi daerah yang bermakna sebagai perluasan kesempatan bagi 
daerah untuk mengejar kesejahteraan dan memajukan dirinya. Ini akan secara significan mengurangi beban pemerintah pusat dan pada saat yang sama menciptakan iklim yang kompetitif diatara daerah-daerah untuk secara kreatif menemukan cara-cara baru dalam mengelola potensi ekonomi yang dimilikinya (Ryaas Rasid , 2007) Sehingga oleh karena dalam kurun waktu tahun 2014 hingga 2019 di Indonesia akan banyak dikembangkan wilayah kerjawilayah kerja baru dan banyak wilayah kerja-wilayah kerja lama yang akan segera berakhir masa kontraknya. Maka situasi ini sebaiknya dimanfaatkan oleh daerah penghasil sebagai momentum bagi daerah untuk mengambil peran lebih nyata, lebih aktif dan lebih progresif dalam mengupayakan keikut sertaan dalam mengelola wilayah kerja migas yang ada di dalam wilayahnya. Tentu saja dengan satu tujuan untuk lebih meningkatkan kesejahteraan masyarakat di daerah. Karena sejauh ini kenyataan yang terjadi justru menunjukkan yang sebaliknya, berbagai kalangan sering mengibaratkan situasi masyarakat di daerah penghasil dengan peribahasa "itik mati di lumbung padi" (Jurnal Serasi, 1993). Sebuah gambaran tragis yang seharusnya menarik perhatian bagi para pengambil kebijakan, untuk mengambil kebijakan yang adil dan proporsional bagi daerah penghasil.

\section{Pengertian dan Syarat Participating Interest (PI)}

Partisipating Interest(PI) adalah istilah yang lazim dalam bidang perusahaan, khususnya dalam bidang pertambangan minyak dan gas bumi (Migas) terutama menyangkut komposisi permodalan atau keikutsertaan. PI adalah suatu hak kesempatan yang diutamakan (previlage) yang diberikan kepada daerah penghasil (Jurnal Analisa) yang djaminan oleh Undang-Undang, untuk turut serta berpartisipasi dalam kegiatan usaha hulu migas terutama dalam kegiatan ekploitasi (produksi) migas yang dilakukan oleh kontraktor (Jurnal Petrominer). Keikut sertaan dilakukan dengan cara menyetorkan modal dan karenanya berhak mendapatkan bagian hasil sesuai keikut sertaannya. PI diberikan secara limitatif berbatas waktu dan tunduk kepada kontrak induk yang dibuat antara pemerintah dan kontraktor. Hubungan antara daerah penghasil dengan kontraktor adalah hubungan dalam kerangka bisnis, karena kontraktor adalah sebuah perusahaan yang bekerja untuk berbisnis. Kontraktor bisa berbentuk Badan Usaha (BU) ataupun Bentuk Usaha Tetap (BUT), yang akan melakukan kegiatan usaha hulu migas berupa ekplorasi dan ekploitasai (produksi) migas dengan tujuan mencari untung dengan tujuan untuk memaksimalkan kesejahteraan pemilik perusahaan (shareholder wealth) (Pudyantoro, 2014).

Definisi tentang PI tidak kita temukan di dalam perundangundangan, namun sebagai perbandingan kita bisa lihat di dalam Code of Federal Regulations of the United States of America, Title 17, Commodity and Securities Exchange,menyebutkanbahwa Participating Interest adalah:

The right of participation in the oil or gas or in the proceeds from the sale of oil or gas, produced from a specivied track or tracts, or well(s), which right is limited 
in duration to the terms of an existing lease and is subject to any portion of expense or development, operation, or maintenance (Code of Federal Regulations of the United States of America).

Partisipating Interest (PI) menurut ketentuan ini adalah hak diikut sertakan untuk berpartisipasi dalam suatu kegiatan ekploitasi (produksi) minyak atau gas bumi di dalam suatu wilayah kerja (wilayah kerja), hak tersebut dibatasi oleh kurun waktu tertentu dan oleh syarat dan ketentuan yang disepakati, yang oleh karenanya pemilik hak berhak untuk mendapatkan bagian hasil (keuntungan) dari penjualan minyak atau gas bumi yang dihasilkan, namun tetap disertai berkewajiban menanggung sebagian beban pengembangan, pengoperasian, atau pemeliharaan (biaya operasional) sesuai dengan besaran hak.

Definisi ini dikuatkan dalam uraian yang lebih padat oleh Charlote J. Wright and Rebecca A. Gallun, bahwa:

Participating Interest means the percentage of the costs and risks of conducting an operation under the Agrement that the party agree, or is otherwise obilagated to pay and bear (Charlotte J. Wright and Rebecca A. Gallun).

Dari kedua definisi ini dapat ditarik benang merah bahwa PI pada dasarnya adalah hak untuk didahulukan atau kesempatan utama untuk ikut berpartisipasi dalam suatu produksi migas, namun Partisipating Interest (PI) bukanlah hak keikutsertaan tanpa syarat, semacam golden right or share yang biasa diberikan oleh perusahaan kepada orang-orang yang diprioritaskan, yang mendapatkan jatah saham karena keahlian, karena pengaruh, dll, tanpa perlu membayar modal (Indra Bastian). Di dalamPI pemilik tetap dibebani dengan kewajiban membayar suatu besaran nilai partisipasi yang disanggupi sesuai kesepakatan dan pada waktunya berhak mendapatkan bagian keuntungan sesuai prosentase keikut sertaan.

Dari bahasan di atas maka beberapa point penting dari PI adalah (1) adanya suatu pemberian hak diutamakan berupa kesempatan untuk berpartisipasi yang diberikan secara berbatas waktu; (2) tetap disertai kewajiban untuk membayar keikut sertaan modal (inbreng) dengan besaran yang disepakati; (3), yang tunduk kepada kontrak induk; (4) dan tetap ikut menanggung risiko rugi; (5), namun berhak mendapatkan porsi keuntungan sebesar keikut sertaan.

Di Indonesia PI diberi batasan yang sangat ketat, karena PI hanya diberikan kepada Pemerintah daerah melalui BUMD (IGN Wiratmaja). Secara garis besar pemerintah telah menetapkan suatu batasan pemberian PI,yakni:

1. Pemda harus membentuk dan menunjuk Badan Usaha Milik Daerah (BUMD) yang pendirian dan penyertaan modalnya berdasarkan peraturan daerah;

2. Penawaran PI $10 \%$ kepada BUMD dilakukan setelah Plant of Development (POD I);

3. Kriteria BUMD kabupaten, kota atau provinsi yang berhak mendapatkan penawaran PI $10 \%$ dengan memerhatikan kewenangan pengelolaan 0-4 
mil laut untuk kabupaten, kota atau provinsi dan 4-12 mil laut untuk provinsi;

4. BUMD harus memiliki kemampuan finansial mandiri untuk membiayai pengambilalihan PI 10\% dan rencana kegiatan operasi berikutnya;

5. BUMD dapat bekerja sama dengan Pusat Investasi Pemerintah (PIP) atau BUMN;

6. Pernyataan minat dan kesanggupan BUMD dalam jangka waktu 60 hari kalender sejak penawaran pertama oleh kontraktor. Apabila tidak ada pernyataan minat penawaran PI kepada BUMD dinyatakan tertutup oleh kontraktor wajib menawarkan PI 10\% kepada BUMN yang ditetapkan oleh menteri;

7. Pengalihan PI $10 \%$ wajib mendapat persetujuan menteri berdasarkan pertimbangan SKK Migas;

8. Wilayah kerja di atas 12 mil merupakan kewenangan pemerintah pusat.

Dengan definisi dan batasan di atas maka semakin memperjelas bahwa sasaran PI adalah untuk memberikan peran dan bagian nyata kepada daerah penghasil untuk tujuan kesejahteraan masyarakat di daerah penghasil. Batasan diatas seharusnya memperkecil kemungkinan terjadi kesalah pahaman dari daerah. Akan tetapi di kalangan pemerintah daerah, selama ini PI dipahami sebagai hadiah keikut sertaan yang diberikan begitu saja tanpa syarat tanpa kewajiban.

Kegiatan usaha hulu migas adalah kegiatan padat modal (hight capital), padat keahlian (hight skill) dan sangat berisiko (hight risk) dan berjangka waktu panjang. Maka kontraktor dengan sistem kontrak kerjasama bagi hasil sangat berhatihati dalam melakukan perhitungan untung dan rugi (Santi DwiDesy Lestari dan Yudha Andrian Saputra ) dan tidak mudah menghamburkan hadiah. Dalam perhitungan kontraktor, kesempatan pertama dan utama untuk turut berpartisipasi saja sudah merupakan hadiah yang benilai ekonomis tinggi bagi suatu daerah. Karena kontraktor sebelum sampai pada tahap ini telah banyak mengeluarkan tenaga dan biaya dalam kegiatan ekplorasi, kegiatan tersebut dilakukan tanpa ada jaminan apapun kecuali keyakinan bahwa upayanya akan menghasilkan migas dalam jumlah memenuhi target ekonomis. Jika ternyata wilayah kerja tersebut gagal menghasilkan migas maka kerugian akan ditanggung oleh kontraktor sendiri. Maka PI adalah berkah bagi daerah dan karenanya inilah saatnya bagi daerah penghasil dengan segala daya dan kemampuannya membangun kapasitas dan kemampuan untuk memanfaatkan kesempatan itu dengan membentuk BUMD (Batubara, 2006).

\section{Posisi Daerah}

Dalam kegiatan usaha hulu migas, Negara berposisi sebagai pemilik migas yang terkandung di bumi Indonesia, mengikatkan diri dalam suatu kontrak kerjasama dengan kontraktor yang berkomitmen sanggup bekerja mengangkat migas dari dalam bumi Indonesia dan untuk upayanya itu berhak menerima imbalan berupa bagian dari hasil migas yang di dapat. 
Jika hubungan hukum antara negara yang diwakili oleh pemerintah sebagai pemegang kuasa pertambangan, dengan kontraktor usaha hulu migas yang berbentuk BU maupun BUT adalah kontrak bagi hasil (Production sharing contract), maka bagian negara Indonesia dan bagian kontraktor telah dirinci sesuai kesepakatan di dalam kontrak (Jurnal Economics and finance in Indonesia). Ketentuan dasar pembuatan kontrak diantara kedua pihak tersebut tidak boleh menyimpang dari Pasal 33 ayat (2) dan (3) UUD 1945, bahwa sumber daya alam yang bersumber dari dalam bumi Indonesia termasuk migas hanya boleh dikuasai oleh negara. Sehingga negara adalah pemilik atau penguasa tunggal. Hal ini sesuai juga dengan ketentuan Pasal 4 ayat (1) dan (2) Undang-Undang Nomor 22 Tahun 2001 tentang Minyak dan gas Bumi. Migas sebagai sumber daya alam strategis tak terbarukan yang terkandung di dalam Wilayah Hukum Pertambangan Indonesia merupakan kekayaan nasional yang dikuasai oleh negara.

Sedangkan Kontraktor Kontrak Kerjasama (KKKS) adalah badan Usaha atau Bentuk usaha tetap yang yang menjalin hubungan kontraktuil dengan Negara, perannya adalah sekedar membantu Negara Indonesia dalam memanfaatkan sumber daya alam migas (http://www.skkmigas.go.id).

Kontraktor yang telah memenuhi syarat dan ditunjuk oleh pemerintah untuk melakukan kegiatan usaha hulu migas dalam waktu yang telah ditentukan, maka wajib dengan dananya, dengan kemampuannya dan dengan segala risikonya, melakukan kegiatan eksplorasi berupa survey penelitian untuk mencari dan memastikan adanya kandungan migas di suatu wilayah kerja. Setelah dari kegiatan ekplorasi ditemukan indikasi adanya kandungan migas yang layak secara ekonomi untuk ditambang atau cadangan terbukti (proven reserve) (Sanusi), maka kegiatan usaha hulu migas akan ditingkatkan ke kegiatan ekploitasi atau produksi, berupa kegiatan mengangkat migas dari perut bumi. Seluruh risiko dari kegiatan eksplorasi maupun eksploitasi tersebut ditanggung atau ditalangi oleh kontraktor sendiri. Satu-satunya jaminan dari seluruh resiko kegiatan eksplorasi dan eksplotasi ini adalah dari migas yang dihasilkan dan dapat diproduksi menjadi komoditi berupa BBM dan BBG dan produk sampingan lainnya. Jika ternyata tidak layak diproduksi maka segala modal yang telah dikeluarkan dalam kegiatan, kerugian yang diderita dan investasi yang sudah dikeluarkan ditanggung oleh kontraktor sendiri, dan negara tidak ikut menanggungnya. Namun jika ternyata dari kegiatan eksploitasi dapat dihasilkan migas dalam jumlah yang menguntungkan, maka dari hasil tersebut sebelum dibagi antara negara dan kontraktor, maka hasil tersebut terlebih dahulu dikurangi dengan biaya-biaya operasional yang telah dikeluarkan oleh kontraktor dalam kegiatan hulu, penggantian dana talangan tersebut disebut cost recovery (http://www.skkmigas.go.id/).

Sampai di tahap ini belum terlalu nyata posisi daerah penghasil dalam kegitan usaha hulu migas. Untuk mendapatkan tanda-tanda yang nyata (tersurat) dimanakah posisi daerah maka harus kita lihat dari aspek yang paling mendasar. Dasar untuk melakukan ekploitasi 
sumber daya alam khususnya migas adalah pada ketentuan Pasal 33 ayat (2) dan (3) UUD 1945, Dimana negara memiliki kekuasaan penuh untuk mengelola sumber daya alam di bumi Indonesia. Terlebih lagi migas termasuk dalam kategori sumber daya alam vital yang menjadi hajat hidup rakyat, sedangkan proses pengelolannya atau produksinya masuk dalam kategori cabang produksi yang dilakukan untuk memenuhi hajat hidup rakyat.

Presiden Joko Widodo dalam suatu kesempatan mengingatkan bahwa amanat konstitusi harus betulbetul diperhatikan karena dengan tegas dan jelas menyatakan bumi dan air serta kekayaan yang terkandung didalamnya dikuasai oleh negara dan dipergunakan untuk sebesarbesarnya kemakmuran rakyat. Dipergunakan untuk sebesarbesarnya kemakmuran rakyat itu mengandung arti bahwa apa yang dihasilkan dalam pemanfaatan sumber daya alam itu harus benarbenar untuk rakyat untuk semua masyarakat Indonesia untuk semua orang dan bukan untuk segelintir atau sekelompok orang.

Sehingga dalam kegiatan hulu migas terdapat dua pihak pelaku utama, yakni Negara dan Kontraktor Kontrak Kerjasama (KKKS). Dalam tulisan ini tidak dibahas lebih lanjut tentang peran negara. Konstitusi menjadi ligitimasi bahwa penguasaan oleh negara pada dasarnya adalah pemerintah pusatlah nantinya yang memiliki wewenang dan akan mendistribusikan kemanfaatan tersebut ke daerah-daerah. Hal ini didasarkan pada argumentasi bahwa bentuk negara Republik Indonesia adalah suatu negara kesatuan (NKRI), sehingga kebijakan yang menyangkut pemanfaatan sumberdaya alam yang strategis dan potensial harus dikuasai dan diatur pengelolaan dan pemanfaatannya oleh Pemerintah Pusat (Dimyati Hartono). Pada tataran konseptual strategi tersebut cukup masuk akal karena akan mengurangi adanya kesenjangan antara daerah-daerah yang secara potensial memiliki sumberdaya alam yang melimpah dengan daerahdaerah yang tidak memiliki sumberdaya alam yang cukup, sehingga tidak akan terjadi kesenjangan ekonomi dan kesejahteraan sosial yang dapat menimbulkan kecemburuan sosial dan politik (Peter M. Blau, 1994). Namun dalam praktenya kesenjangan ternyata tetap terjadi, terutama bisa kita lihat antara Indonesia Timur dan Barat.

Sedangkan BU dan BUT berperan sebagai kontraktor yang lazim disebut sebagai Kontraktor Kontrak Kerjasama (KKKS). Di seluruh Indonesia berdasar data SKK Migas terdapat 184 KKKS eksplorasi, 79 KKKS produksi dan KKKS CBM (http://www.migas.esdm.go.id).

Untuk sampai pada tahap mengikatkan diri dalam suatu kontrak dengan Negara, KKKS telah melakukan berbagai proses pendahuluan, yang diawali dengan mengikuti tender penawaran wilayah kerja, penunjukan sebagai kontraktor wilayah kerja, ekplorasi dan ekplotiasi. PI akan disampaikan kepada daerah penghasil pada tahap ekploitasi (produksi). Setelah dari proses ekplorasi didapat kepastian pada wilayah kerja tersebut ditemukan kandungan migas yang potensial secara keekonomian, dan kemudian dilakukan penelitian pendalaman oleh kontraktor sehingga 
statusnya ditingkatkan menjadi cadangan terbukti, maka Kontraktor selanjutnya akan melakukan kegiatan produksi yang didahului dengan penerbitan izin produksi oleh pemerintah. Pada saat kontraktor mengajukan rencana pengembangan yang pertama kali (Plant of development) inilah ditentukan syarat kepada kontraktor untuk melibatkan daerah penghasil untuk ikut berpartisipasi dalam kegiatan produksi, dengan cara menawarkan kepada daerah penghasil untuk berperan serta dalam kegiatan produksi (Pasal 11 Peraturan Menteri ESDM Nomor 6 Tahun 2010). Dasar hukum yang mengharuskan adanya Participating Interest (PI) adalah Peraturan Pemerintah Republik Indonesia No. 35 Tahun 2004 tentang Kegiatan Usaha Hulu Minyak dan Gas Bumi pada:

\section{Pasal 34:}

Sejak disetujuinya rencana pengembangan lapangan yang pertama kali akan diproduksi dari suatu wilayah kerja, kontraktor wajib menawarkan participating interest $10 \%$ (sepuluh persen) kepada badan usaha milik daerah

\section{Pasal 35:}

(1) pernyataan minat dan kesanggupan untuk mengambil participating interest sebagaimana dimaksud dalam pasal 34 disampaikan oleh Badan Usaha Milik Daerah dalam jangka waktu paling lama 60 (enam puluh) hari sejak tanggal penawaran dari kontraktor

(2) dalam hal Badan Usaha Milik Daerah tidak memberikan pernyataan kesanggupan dalam jangka waktu sebagaimana dimaksud dalam ayat (1), kontraktor wajib menawarkan kepada Perusahaan Nasional.

(3) dalam hal Perusahaan Nasional tidak memberikan pernyataan minat dan kesanggupan dalam jangka waktu paling lama 60 (enam puluh) hari sejak tanggal penawaran dari kontraktor kepada Perusahaan Nasional, maka penawaran dinyatakan tertutup.

Berdasarkan ketentuan Pasal 35 ayat (1), ayat (2) dan ayat (3) maka prioritas utama PI sebesar 10\% diberikan pada Badan Usaha Milik Daerah (BUMD) dengan jangka waktu penawaran paling lama 60 hari sejak tanggal penawaran dari kontraktor. Apabila BUMD tidak memberikan pernyataan kesanggupan dalam jangka waktu tersebut, kontraktor wajib menawarkan kepada perusahaan nasional. Apabila perusahaan nasional tidak memberikan pernyataan minat dan kesanggupan dalam jangka waktu 60 hari sejak tanggal penawaran, maka penawaran dinyatakan tertutup. Untuk memenuhi syarat modal dan syarat waktu ini tentu sangat sulit bagi daerah penghasil.

Daerah penghasil adalah daerah yang wilayahnya meliputi wilayah kerja kontraktor. Batasannya adalah daerah yang mewilayahi bukan kedekatan lokasi, seperti Wilayah kerja Natuna D-Alpha secara geografis lebih dekat ke Pontianak Kalimantan Barat dibanding dengan Kepulauan Riau yang mewilayahi. Wilayah kerja Masela lebih dekat ke Kupang NTT dari pada ke Ambon yang mewilayahi. Wilayah kerja Cepu ada 4 daerah yang mewilayahi yakni Kabupaten Bojonegoro dan Propinsi 
jawa Timur serta Kabupaten Blora dan Propinsi Jawa Tengah, wilayah kerja Madura Strait yang mewilayahi Kabupaten Sampang dan Sumenep, wilayah kerja Kangean yang mewilayahi Kabupaten Sampang dan Propinsi jawa Timur. Sehingga pendekatannya adalah pendekatan administratif pemerintahan bukan pendekatan geografis. Jika di lapangan ternyata wilayah kerja tersebut berada di wilayah yang terdiri satu atau lebih pemerintah daerah maka dilakukan kesepakatan pembagian diantara daerah secara adil proporsional.

Sebagai contoh adalah kesepakatan pembagian PI Wilayah kerja Cepu yang mengandung gas 6 triliun TCF dan 490 juta barel minyak. Kesepakatan ditandatangani di Hotel Sangrila Surabaya (Kesepakatan Sangrila), yang dibuat di hadapan Presiden SBY, Gubernur Jatim Imam Utomo, Gubernur Jawa Tengah Mardiyanto, Bupati Bojonegoro HM Santoso, Bupati Blora Basuki Widodo. Kesepakatannya, PI Wilayah kerja Cepu sebesar 10 \%, dibagi dengan bagian pemerintah daerah Jawa Timur memperoleh 6,7 \%, Jawa Tengah 3,3 \%. Dari 6,7 \% yang diperoleh Jatim, Bojonegoro mendapat 4,5 \% dan Pemprof Jatim memperoleh 2,2 \% (Tomi Lebang, 2006).

\section{Ketentuan Perundang-undangan Sebagai Dasar Partcipating Interest.}

Setelah jangka waktu kontrak di suatu wilayah kerja berakhir, maka berdasarkan Pasal 7 ayat (3) PP 35 Tahun 2004, kontraktor wajib mengembalikan wilayah kerja tersebut kepada negara. Jika dalam wilayah kerja tersebut dinilai masih potensial, maka sebagaimana diatur di dalam Pasal 3 PP 35 Tahun 2004, Menteri menetapkan dan mengumumkan wilayah kerja yang akan ditawarkan kepada BU dan BUT dengan cara lelang maupun penawaran langsung. Dalam penetapan Wilayah Kerja sebagaimana dimaksud di atas, Menteri berkonsultasi dengan Gubernur yang wilayah administrasinya meliputi Wilayah Kerja yang akan ditawarkan. Konsultasi ini adalah dialog yang berisi pemberian informasi mengenai wilayah kerja dimaksud dan meminta informasi yang berkaitan. Ketentuan ini menempatkan daerah sebagai pihak yang turut menentukan dalam pengambilan kebijakan, selain menyiratkan suatu keharusan untuk menyerap aspirasi daerah. Karena dalam kesempatan ini daerah akan berkesempatan untuk menyampaikan aspirasinya yang bisa saja berbentuk saran dan pendapat dan tentu saja syarat-syarat yang diminta oleh daerah (Kumpulan Tulisan Dunia EKUIN).

Hak hak daerah untuk memperoleh bagian dari penerimaan Negara dari migas, semakin mendapat penguatan secara legal formil dari ketentuan UndangUndang Nomor 32 Tahun 2004 tentang Pemerintah Daerah yang memiliki misi bahwa dalam rangka penyelenggaraan pemerintahan daerah sesuai dengan amanat UUD 1945, pemerintahan daerah, yang mengatur dan mengurus sendiri urusan pemerintahan menurut asas otonomi dan tugas pembantuan, diarahkan untuk mempercepat terwujudnya kesejahteraan masyarakat melalui peningkatan, pelayanan, pemberdayaan, dan peran 
serta masyarakat, serta peningkatan daya saing daerah dengan memperhatikan prinsip demokrasi, pemerataan, keadilan, keistimewaan dan kekhususan suatu daerah dalam sistem Negara Kesatuan Republik Indonesia (A.M. Fatwa). Ditambah lagi dalam ketentuan dalam UndangUndang Nomor 30 Tahun 2007 tentang Energi, bahwa peranan energi sangat penting artinya bagi peningkatan kegiatan ekonomi dan ketahanan nasional, sehingga pengelolaan energi yang meliputi penyediaan, pemanfaatan, dan pengusahaannya harus dilaksanakan secara berkeadilan, berkelanjutan, optimal, dan terpadu.

$$
\text { Begitupun Undang-Undang }
$$

Nomor 33 Tahun 2004 tentang Perimbangan antara Pemerintah Pusat dan Pemerintah Daerah. Semangat dari ketentuan ini adalah bahwa UUD 1945 mengamanatkan diselenggarakan otonomi seluasluasnya dalam kerangka Negara Kesatuan Republik Indonesia. Sehingga hubungan keuangan, pelayanan umum, pemanfaatan sumber daya alam dan sumber daya lainnya antara Pemerintah Pusat dan Pemerintahan Daerah, dan antar Pemerintahan Daerah perlu diatur secara adil dan selaras. Perimbangan keuangan antara Pemerintah dan Pemerintahan Daerah adalah suatu sistem pembagian keuangan yang adil, proporsional, demokratis, transparan, dan efisien dalam rangka pendanaan penyelenggaraan Desentralisasi, dengan mempertimbangkan potensi, kondisi, dan kebutuhan daerah (Syamsuddin Haris, 2007).

Sebelum lebih lanjut, ketentuan tentang bagi hasil dan perimbangan keuangan ini sebatas menyangkut dana yang di dapat dari bagian Negara dari hasil production sharing contract yang telah disetor ke kas Negara, sedangkan PI adalah diluar dari kerangka pengertian itu. Salah satu sumberdana perimbangan antara pemerintah pusat dan pemerintah daerah adalah dana bagi hasil yang bersumber dari migas sebagaimana diatur dalam Pasal 11 ayat (3) Undang-Undang Nomor 33 Tahun 2004. Dalam Undang-Undang tersebut pula, di atur dalam Pasal 19, bahwa Penerimaan pertambangan migas yang dibagikan ke daerah adalah penerimaan dari sumbar daya alam migas yang ada di wilayah daerah yang bersangkutan setelah dikurangi pajak dan pungutan lainnya.

Norma-norma yang terkandung dalam ketiga undang-undang di atas menyiratkan suatu misi tentang: (1) Penghargaan kepada daerah yang; (2) berkeadilan dan proporsional serta tuntutan agar; (3) daerah lebih mandiri sebagai daerah otonom, namun dengan tetap mencari peluang dari potensi dan keunggulan daerah dan mendapatkan; (4) bagian yang proporsional dari skema keuangan pusat dan daerah. Norma-norma yang mengangkat derajat daerah penghasil tersebut telah menginspirasi untuk lebih memperkuat PI. PI sangat penting, karena sudah selayaknya daerah penghasil mendapatkan kompensasi yang memadai dengan mempertimbangkan berbagai aspek. Bagian daerah seharusnya memperhitungkan pula biaya restorasi sosial dan lingkungan sebagai dampak ekplorasi dan ekploitasi. Dampak kerusakan sosial dan lingkungan ini tidak sedikit, untuk memperbaikinya bukanlah pekerjaan ringan dan diperlukan 
biaya yang tidak murah (Agoes Soegiant0, 2005). Faktanya kebanyakan daerah tidak berhasil melakukan restorasi itu dan kehidupan masyarakat justru semakin terpuruk dan jurang kesenjangan ekonomi semakin menganga. Oleh karenanya dasar pemberian PI kepada daerah penghasil juga harus mencerminkan kebutuhan daerah atas restorasi kerusakan sosial dan lingkungan.

Berangkat dari posisi dan pemikiran berbagai ketentuan di atas, maka hal pertama yang akan dilakukan saat dimulainya pengelolaan suatu wilayah kerja adalah membuat "Plant of Development". Berdasarkan ketentuan Pasal 34 Peraturan Pemerintah Nomor 35 Tahun 2004, setelah Plant of Development pertama tersebut disetujui timbulah "kewajiban" dari kontraktor untuk memberikan panawaran "Participating Interest" sebanyak 10 $\%$ kepada daerah penghasil melalui Badan Usaha Milik Daerah (BUMD). Untuk selanjutnya, peran serta daerah setempat akan dijalankan oleh BUMD melalui mekanisme bisnis kegiatan usaha hulu migas. Sebagai alat otonomi daerah BUMD harus dapat berperan dalam mendorong pertumbuhan perekonomian daerah (agent of development). Sebagai salah satu sumber pendapatan asli daerah (PAD), BUMD juga diharuskan memiliki kedudukan yang strategis dalam sistem dan struktur perekonomian daerah dan dapat berperan sebagaimana mestinya tanpa meninggalkan fungsi sosialnya (MalangJoeda, 2006). Mengapa PI bukan diberikan kepada pemerintah daerah sebagai badan hukum publik namun diberikan kepada BUMD.
Karena pemberian PI kepada daerah penghasil lebih berorientasi bisnis dibanding sekedar pemberian hak kewilayahan dan pemerintahan.

\section{Kesiapan Daerah}

Tidak semua daerah memiliki kesiapan dalam memanfaatkan PI. Ketidak siapan tersebut lebih dikarenakan kurangnya pemahaman aturan migas dan kemampuan membaca peluang bisnis. Banyak daerah bahkan sering mengandalkan jatah dari pusat tanpa mau berinisitif dan berinovasi memanfaatkan peluang PI. Jika dikelompokkan dalam beberapa sebab ketidak siapan tersebut adalah pada: Sumberdaya manusia, khususnya ahli dalam bidang migas, masih langka; (2) Naluri bisnis yang tumpul dan terbiasa terima bagian jadi, (3) Kolusi Korupsi Nepotisme (KKN) (Amien Rais); (4) Lemah Sarana dan Prasarana, Transparansi dan sosialisasi.

Keikut sertaan BUMD dalam sebuah proyek hulu migas menuntut pemahaman yang cukup tentang mekanisme kegiatan usaha hulu migas. Keikut sertaan tidak akan berjalan maksimal jika tidak terjun langsung dan mengawasi kegiatan produksi. Dengan cara itu BUMD dapat lebih maksimal memberikan kontribusi bagi kemajuan kegiatan usaha hulu migas juga sekaligus mengawasi kegiatan usaha agar tidak terjadi kebocoran sehingga mendatangkan hasil yang lebih optimal. Maka BUMD harus merekrut tenaga-tenaga ahli yang berkompeten dan relevan dengan bidang tugas itu, rekrutmen itu tidak harus mensyaratkan putra daerah. Guna tercapainya peranan yang diharapkan, baik untuk pertumbuhan 
ekonomi daerah maupun peningkatan $\mathrm{PAD}$, pola pengelolaan BUMD harus diarahkan pada pencapaian efisiensi, efektivitas, dan produktivitas kerja, serta pada upaya optimalisasi sumber daya dan sumber dana yang dimiliki.

Keikut sertaan daerah berarti keikut sertaan dalam melakukan bisnis migas. Bisnis dimanapun di dunia ini bertujuan mencari untung semaksimal mungkin (profit oriented). Untuk mengejar keuntungan tersebut diperlukan berbagai upaya yang berbasis pada tiga kegiatan yakni perencanaan (planning), eksekusi rencana atau pelaksanaan (executing) dan evaluasi perkembangan dan hasil (evaluating). PI bukanlah durian runtuh, karena PI harus disertai dengan pengoptimalan potensi, melakukan inovasi dan terus dari waktu kewaktu mengefektifkan penggunaan hasil usaha bisnis tersebut diarahkan untuk membiayai pengembangan. Dibutuhkan instink bisnis dan kapasitas yang memadai, sehingga pemda jangan memandang pengurusan PI ini dengan sebelah mata.

Beberapa daerah bahkan menunjukkan gejala gagap dan terbiasa pasrah menerima jatah apapun dari pusat, sebagian lagi bahkan menuntut PI lebih dari $10 \%$ dengan disertai kegaduhan, demontrasi masa dan pemblokiran wilayah kerja, dll. Padahal jika dipahami maksud dan tujuan dan mekanisme PI kepada daerah, PI adalah hak dan kesempatan untuk mendapatkan pendapatan asli daerah yang cukup potensial. Maka daerah penghasil seharusnya tidak dalam posisi pasif, tapi harus aktif memperjuangkan haknya tersebut dengan berperan aktif namun konstruktif dan produktif untuk keberhasilan industri migas di wilayahnya tersebut. Namun yang terjadi justru sebaliknya, daerah penghasil karena keterbatasan dana dan pemahaman, bahkan sering melemparkan begitu saja haknya kepada mitra swasta, sehingga lagilagi PI menjadi tidak tepat sasaran, namun justru mensejahterakah pemilik modal yang datang dari luar daerah, akibatnya menyimpang dari tujuan filosofis dari PI.

Ada baiknya saham BUMD harus murni berasal dari keuangan daerah dan tidak perlu melibatkan investor luar daerah, agar keuntungan benar-benar dalam penguasa daerah. Menurut M. Amien Rais, Di daerah tertentu sikap demikian menimbulkan masalah KKN dan di beberapa daerah muncul sebagai berita Korupsi di media masa. Sebagai contoh PI pengelolaan Wilayah kerja Cepu di Lingkungan Kabupaten Bojonegoro yang dinilai merugikan daerah dan mengerdilkan peran BUMD PT. Asri Dharma Sejahtera dan lebih didominasi oleh pihak swasta PT. Surya Energi Raya (http://news.okezone.com). Di Wilayah kerja Madura offshore pada Kabupaten Sumenep, PT. Wira Usaha Sumekar (WUS) dilaporkan ke Komisi Pemberantasan Korupsi (KPK). Badan Usaha Milik pemerintah Darah (BUMD) Kabupaten Sumenep, Madura, Jawa Timur, itu diduga terkait dengan dugaan korupsi dana penyertaan participating interest (PI) di perusahaan minyak bumi dan gas sebesar Rp 8,8miliar. Adalah Lembaga Swadaya Masyarakat (LSM) Sumenep yang melaporkan dugaan itu pada 2013 (http://www.maduraexpose.com). 
Melihat situasi di atas maka terlihat bahwa Hak daerah dalam pengusahaan sektor hulu Migas secara langsung tidak diimbangi oleh pemahaman, kemampuan teknis dan keuangan BUMD. Akibatnya situasi ini sering kali dimanfaatkan oleh pihak swasta dan kroninya untuk mendapat rente dari sektor Migas. Maka benar adanya rekomendasi Tim Reformasi Tata Kelola Migas agar PI yang menjadi hak daerah dipastikan pemanfaatan sepenuhnya oleh daerah melalui badan Usaha Milik daerah (BUMD) yang sepenuhnya dimiliki Daerah. Untuk itu, perlu disusun aturan perundangan yang mengatur partisipasi BUMD pada pengusahaan sektor hulu migas, termasuk di dalamnya kewajiban kerja sama antara BUMD dengan Pertamina, tanpa membebani BUMD dengan pengeluaran biaya investasi dan risiko kerugian usaha.

Posisi BUMD dalam hubungan dengan PI sangat penting. Peluang dan tantangan yang dimiliki BUMD tidak ringan karena dituntut untut mampu mnyesuaikan diri dengan perilaku bisnis yang timbul sejalan dengan liberalisasi investasi dan perdagangan bebas yang menuntut kompetisi yang sangat tajam, penerapan standart bisnis internasional, dan kecenderungan privatisasi. Hal ini menuntut BUMD untuk selalu berorientasi pada pemikiran dan perilaku bisnis secara professional serta ke-entreprenuranan. Sedang kenyataannya BUMD menghadapi problem-problem lemah pemahaman bisnis dan bidang usaha yang dimasuki, inefisiensi kelembagaan dan struktur organisasi usaha BUMD berakibat biaya mahal, SDM yang dimiliki berkualitas rendah dan yang paling menonjol adalah problem intervensi politik dari pengauasa kepada BUMD.

Dalam hal PI, lemahnya kemampuan pembiayaan adalah penyebab utama munculnya penyelewengan. Karena PI adalah hak maka daerah yang mewilayahi adalah pihak satu satunya yang bisa mendapatkan. Namun sayang tidak semua daerah mempunyai BUMD dengan kemampuan yang cukup untuk mengganti PI senilai $10 \%$ tersebut. Akibatnya orang-orang daerah akan berlomba-lomba mencari pendana (investor) dari luar daerah, bahkan kadang disertai motif sekedar menjadi calo. Karena PI mengandung keuntungan yang cukup besar, maka para investor akan sangat tertarik untuk berinvestasi. Maka dengan berbagai cara mereka akan merumuskan skema hubungan dengan BUMD yang seringkali justru menempatkan daerah dalam nilai tawar yang sangat rendah. Pada saat itulah sering terjadi KKN dengan tokoh daerah dan pusat sehingga mengorbankan kepentingan daerah dan lebih menguntungkan investor.

\section{Wilayah kerja Masela dan Participating Interest Bagi Propinsi Maluku dan Kabupaten Maluku Tenggara Barat}

Wilayah kerja Masela bukan wilayah kerja lama, namun wilayah kerja baru yang belum pernah berproduksi dan akan segera berproduksi. Kontrak kerjasama Wilayah kerja Masela ditandatangani pada 16 November 1998, saat itu belum ada PI. Wilayah kerja ini mendapat persetujuan POD I pada tanggal 6 Desember 2010. Sehingga dalam kaitan PI, tahap sekarang ini merupakan kesempatan yang berharga bagi Pemerintah Propinsi 
Maluku khususnya Kabupaten Maluku Tenggara Barat untuk aktif menyampaikan aspirasinya. Hal itu karena masih ada kendala berkaitan dengan ketentuan bahwa PI dibatasi oleh jarak antara lokasi dengan garis pantai terdekat. Kewenangan untuk kabupaten 0-4 mil, kewenangan provinsi hingga 12 mil dan di atas 12 mil menjadi kewenangan pemerintah pusat, sementara Wilayah kerja Masela jaraknya sekitar $150 \mathrm{~km}$ dari garis pantai Maluku (http://www.migas.esdm.go.id).

Wilayah kerja Masela dengan kontraktor PT. Inpex Masela Limited memiliki luas area lebih kurang $4.291,35 \mathrm{~km}^{2}$. Wilayah kerja migas ini terletak di Laut Arafura, sekitar 800 km sebelah timur Kupang, Nusa Tenggara Timur atau lebih kurang $400 \mathrm{~km}$ di utara kota Darwin, Australia, dengan kedalaman laut 300-1000 meter (http://www.migas.esdm.go.id).

Inpex Masela akan segera mengembangkan Lapangan Gas Abadi yang terletak di Lepas Pantai Laut Arafura, dengan kedalaman laut sekitar antara 400- 800 meter, berjarak kurang lebih $150 \mathrm{~km}$ barat daya Saumlaki, merupakan Ibu Kota Kabupaten Maluku Tenggara Barat, Provinsi Maluku (http://www.petrominer.co.id).

Wilayah kerja Masela yang terletak di Laut Arafura, Maluku ini berdasarkan survey memiliki potensi cadangan gas terbukti sangat besar. Berdasarkan data dari Kantor staf Kepresidenan dan data Lemigas tahun 2015, cadangan terbukti Wilayah kerja Masela mencapai 10,73trillion cubic feet (tcf) (http://ksp.go.id/wilayah).

Menurut penelitian geologis yang dilakukan oleh LEMIGAS, Wilayah kerja Masela akan dikembangkan menjadi daerah produksi gas melalui Lapangan Abadi pada batuan Jurasik sebagai target leads mengandung hidrokarbon. Saat ini telah dilakukan beberapa persiapan untuk mendorong produksi, seperti Feasability Study untuk sistem pemipaan ke daerah penampungan di P.Yamdena, Kep. Tanimbar. Pengembangan Wilayah kerja Masela,akan dilanjutkan dengan pengembangan Wilayah kerja West Masela dan Wilayah kerja Babar. Untuk menyalurkan gas dari Wilayah kerja Masela akandilakukan beberapa alternatif, seperti jalur pipa ke arah pulau-pulau terdekat dan atau melalui sistem floating (mengapung). Beberapa pulau yang menjadi prioritas adalah selatan P. Babar yang berjarak $152 \mathrm{~km}$ dan barat daya $P$. Yamdena yang berjarak $146 \mathrm{~km}$ dari Wilayah kerja Masela. Lokasi (Perairan Wilayah kerja Masela, Perairan Kep. Tanimbar) merupakan daerah yang akan segera memproduksi gas dari Lapangan Abadi. Secara geografi terletak di selatan Pulau Masela (Provinsi Maluku) pada koordinat antara 129o00'00" - 132000'00" BT dan 08000'00" - 10000'00" LS (http://www.lemigas.esdm.go.id). Profil Wilayah Kerja Wilayah kerja Masela:

- Wilayah kerja Masela yang dioperasikan oleh KKKS INPEX Masela Ltd. terletak di lepas pantai, yaitu di Laut Arafura sekitar $155 \mathrm{~km}$ arah Barat Daya kota Saumlaki, dan sisi Selatan Wilayah kerja Masela tepat pada perbatasan perairan Indonesia Australia;

- Adapun kedalaman laut di sekitar lokasi kegiatan pemboran berkisar antara 500 sampai 800 
meter, selanjutnya pemboran keempat sumur tersebut akan dilakukan sampai kedalaman sekitar 4,000 meter dari dasar laut;

- Izin wilayah kerja mulai berlaku pada 16 November 1998;

- Inpex menguasai $65 \%$ saham, sedangkan sisa-nya dimiliki Shell;

- Tipe kontrak untuk Wilayah kerja Masela adalah bagi hasil;

- Luas wilayah Wilayah kerja Masela mencapai $1.200 \mathrm{~km}^{2}$;

- Kegiatan eksplorasi berlangsung sejak 1998 hingga 2008;

- Inpex mendapat persetujuan rencana pengembangan lapangan Abadi pada Desember 2010.
Dalam Plan of Development pertama (POD I) yang disetujui Desember 2010, KKKS akan membangun kilang LNG terapung dengan kapasitas 7.5 juta ton per tahun (MTPA). Fasilitas yang membutuhkan investasi besar dan diharapkan dapat mulai berproduksi pada akhir 2016;

- Berdasarkan rencana pengembangan 2010, Wilayah kerja Masela ditargetkan memproduksi gas sebesar 355 juta kaki kubik per hari (million standard cubic feet per day / MMscfd) (http://www.skkmigas.go.id/);

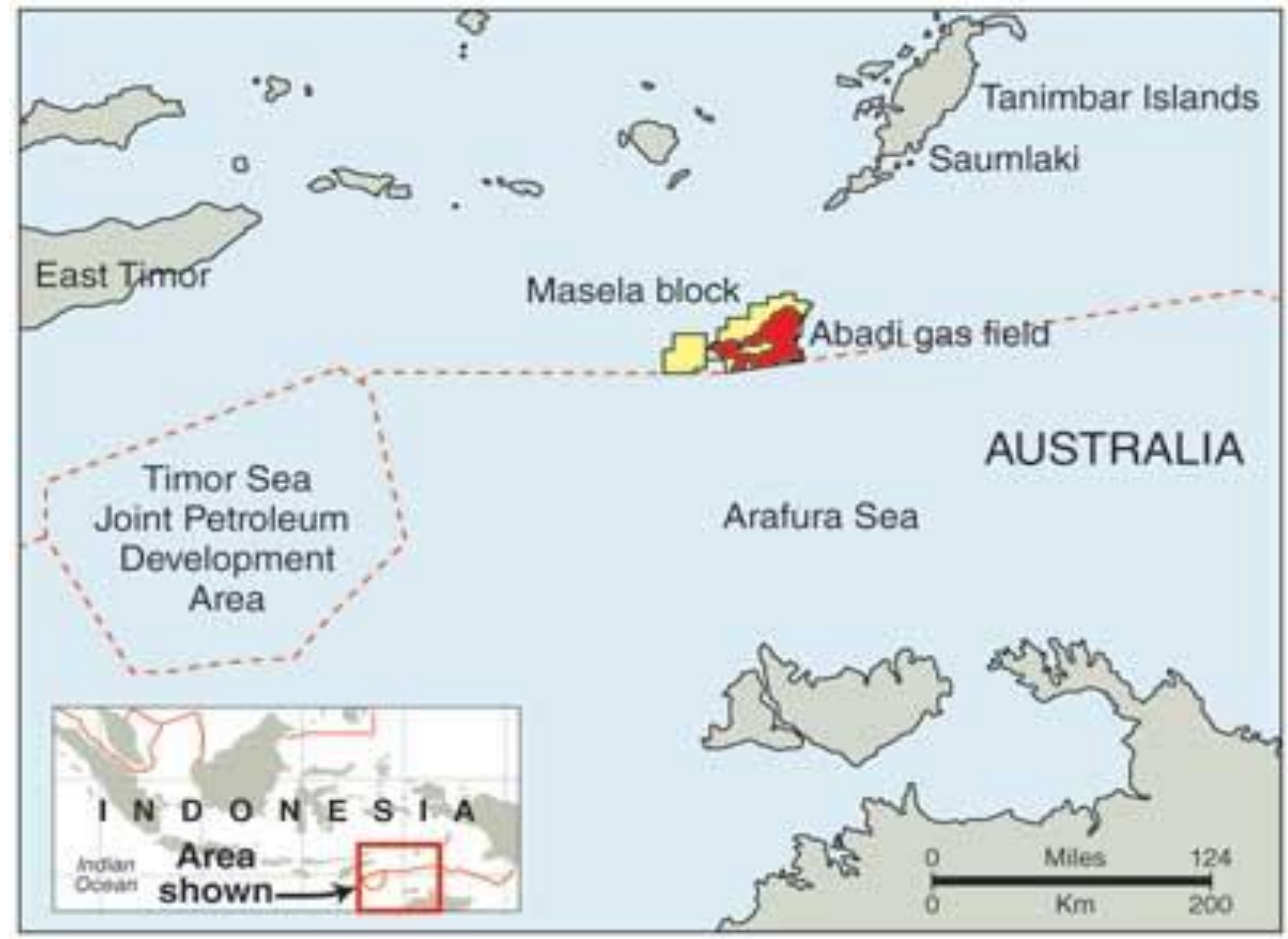

(Gambar Peta Lokasi Wilayah kerja Masela, http://industri.bisnis.com/)

Pengembangan wilayah kerja Masela diharapkan memberi manfaat lebih nyata bagi daerah penghasil. Daerah penghasil yang mewilayahi selain mendapatkan hasil dari hasil pembagian danaperimbangan keungan pusat dan daerah juga harus mendapatkan bagian dari hak partisipasi. SKK Migas merekomendasikan tiga skenario untuk wilayah kerja minyak dan gas baru maupun yang akan habis masa kontraknya yaitu: (1) Untuk wilayah kerja yang memiliki kinerja operator tinggi sekaligus potensi cadangan banyak, dapat dipertimbangkan 
diberikan perpanjangan dengan melibatkan PT Pertamina dan BUMD sebagai pemegang hak partisipasi; (2) Wilayah kerja yang memiliki kinerja operator rendah, namun memiliki potensi cadangan tinggi, dapat diberikan kepada Pertamina sebagai operator dengan melibatkan BUMD dan kontraktor eksisting sebagai pemegang hak partisipasi; (3) Wilayah kerja yang memiliki kinerja operator rendah sekaligus potensi cadangan rendah, dilakukan tender terbuka

(http://www.kabarbisnis.com).

Wilayah kerja Masela ada di dalam wilayah kabupaten Maluku Tenggara Barat Propinsi Maluku. Dengan demikian BUMD Kabupaten Maluku Tenggara Barat dan Propinsi Maluku memiliki kesempatan untuk memanfaatkan PI dalam pengelolaan wilayah kerja Masela dimana haknya tersebut dijamin oleh peraturan perundang-undang dibidang migas. Untuk selanjutnya yang harus diperhatikan dan diwaspadai adalah agar hak Partsisipasi ini tidak salah sasaran dan justru menguntungkan swasta. Mengapa situasai ini harus menjadi perhatian khusus, karena Propinsi Maluku dan Kabupaten Maluku Tenggara Barat adalah daerah tertinggal dengan kemampuan dana yang terbatas. Meminta kedua daerah penghasil ini untuk menyiapkan dana modal keikut sertaan dalam PI ini tentu sangat berat. Sedangkan saat ini pihak swasta sudah mulai memainkan pengaruhnya untuk mengambil PI wilayah kerja Masela itu. Di awal masa jabatan kabinet Jokowi-JK, menteri ESDM membentuk Tim Reformasi Tata Kelola Migas, dalam laporannya, tim menyerahkan 12 rekomendasi laporan yang berjudul
"Memperkokoh Kelembagaan Sektor Migas Indonesia". Salah satu Rekomendasi yang diberikan adalah, Participating Interest yang menjadi hak daerah agar dipastikan sehingga mendatangkan kemanfaatan yang dijalankan oleh BUMD yang sepenuhnya dimiliki daerah. Untuk itu, perlu disusun aturan perundangan yang mengatur partisipasi BUMD pada pengusahaan sektor hulu migas, termasuk di dalamnya kewajiban kerja sama antara BUMD dengan Pertamina, tanpa membebani BUMD dengan pengeluaran biaya investasi dan risiko kerugian usaha. Rekomendasi itu merupakan aspirasi dari daerah penghasil migas yang selama ini belum terpecahkan dan menyisakan banyak masalah hingga saat ini.

Participating Interest yang menjadi hak Daerah harus dipastikan pemanfaatan sepenuhnya oleh Daerah melalui BUMD yang sepenuhnya dimiliki Daerah. Dengan pemberian PI kepada daerah juga memberikan dampak dan peluang kepada daerah untuk maju. Agar PI tepat sasaran, pengaturan PI juga harus disertai ketentuan mengenai pemanfaatan potensi daerah untuk menunjang wirausaha lokal, peluang pelatihan, pengembangan keterampilan, serta dukungan finansial yang mungkin tersedia agar mereka dapat berperan serta di setiap mata rantai nilai industri migas. Daerah berhak mendapatkan manfaat optimal dari pengusahaan sumber daya alam migas di wilayahnya. Pengusahaan sektor hulu migas memberi manfaat kepada daerah melalui keterlibatan BUMD secara langsung. Hal tersebut menegaskan bahwa PI yang menjadi hak daerah harus dipastikan 
dimanfaatkan oleh daerah. Untuk itu perlu disusun aturan perundangan yang mengatur partisipasi BUMD pada pengusahaan sektor hulu migas. Termasuk di dalamnya kewajiban kerja sama antara BUMD dengan Pertamina atau dengan lembaga pembiayaan Negara lainnya, sehingga PI tidak membebani daerah dengan biaya investasi dan kerugian usaha. Dalam jangka panjang perlu dipertimbangkan untuk menata kembali skema pembagian pendapatan negara dari sektor hulu migas kepada daerah sehingga daerah dapat memperoleh pendapatan yang lebih pasti dan adil.

Belakangan ini Kementerian Energi dan Sumber Daya Mineral, justru akan semakin memperketat perolehan PI dengan menjabarkan delapan poin penting yang dituangkan pada Peraturan Menteri ESDM tentang Participating Interest (PI) $\quad 10 \% \quad$ Pemerintah Daerah (Pemda) dalam Wilayah Kerja (WK) Migas. Pemberian PI 10\% ini hanya diberikan pada WK migas yang telah habis masa kontraknya, pertanyaan yang muncul adalah bagaimana dengan WK yang baru seperti wilayah kerjaMasela. BUMD hanya diperbolehkan menggandeng Pusat Investasi Pemerintah (PIP) atau BUMN untuk memiliki 10\% hak partisipasi (participating interest) wilayah kerjaminyak dan gas. Alasan pelarangan itu adalah untuk memberikan manfaat maksimal bagi daerah dan mencegah pemburu rente masuk menguasai wilayah kerjamigas melalui

BUMD

(http://www.bumn.go.id).

Dalam menanggapi batasan tersebut banyak daerah penghasil berharap pemerintah pusat bisa membantu daerah agar benar-benar bisa merealisasi hak daerah mendapatkan PI dari industri migas. Jika BUMD dilarang merangkul investor, maka pemerintah harus membuat aturan yang memungkinkan daerah tetap mendapatkan PI. Jangan hanya melarang Pemda merangkul investor, tapi harus ada solusinya. Misalnya dengan pola golden share. Kalau pola golden share disetujui, mungkin PI daerah tidak harus $10 \%$, tetapi itu lebih jelas karena Pemda bisa menikmati PI.

Selaian kendala lemahnya pemahaman, permodalan dan KKN, PI bagi daerah penghasil akan berhadapan dengan PI pemerintah Pusat yang dijalankan dan dikelola oleh Pertamina. Karena dalam rangka memastikan terwujudnya ketentuan konstitusi, selain kepada BUMD pemerintah juga mendorong agar PT. Pertamina (Persero) diusulkan memperoleh saham partisipasi atau participating interest (PI) dalam wilayah kerja-wilayah kerja minyak dan gas bumi (migas) yang kontraknya akan diperpanjang dan sebaiknya hak tersebut dimasukkan dalam Peraturan Menteri ESDM tentang perpanjangan kontrak wilayah kerja migas. Dengan memiliki PI, maka Pertamina bisa terlibat langsung dalam pengelolaan wilayah kerja-wilayah kerja migas yang selama ini dipegang oleh perusahaan migas asing. Dengan demikian, Pertamina diharapkan memperoleh transfer teknologi dan pengetahuan dari perusahaan-perusahaan migas internasional. Kalangan profesional di bidang perminyakan menyarankan pemerintah memberikan 55\% - 60\% wilayah kerja minyak dan gas bumi (migas) kepada PT. Pertamina (Persero). Semakin besar pengelolaan 
migas oleh badan usaha milik negara (BUMN) maka akan semakin besar keuntungan yang diperoleh negara. Saat ini mengacu informasi Komisi Pemberantasan Korupsi, Pertamina hanya mengelola $21 \%$ dari total wilayah kerja yang ada di Indonesia. Negara akan menerima manfaat $100 \%$ dari hasil pengusahaan migas jika wilayah kerja dikelola Pertamina. Kemudian pemerintah diminta tidak hanya fokus pada penerimaan fiskal dalam mengelola industri migas. Dalam pengembangan lapangan migas baru, pemerintah harus memiliki paradigma untuk mengembangkan operasi migas di daerah tersebut.

Selain tantangan dari adanya ketentuan PI kepada PT. Pertamina (Persero), PI bagi daerah penghasil juga akan berhadapan dengan upaya KKKS untuk memperoleh bagian yang paling menguntungkan. Upaya KKKS ini tentu saja bertentangan dengan misi daerah penghasil untuk ikut serta dalam bisnis migas dengan jatah PI yang sebesar-besarnya. Maka sesuai dengan hukum bisnis liberal, KKKS sedapat mungkin akan berusaha tidak melibatkan daerah penghasil, karena dimata KKKS keterlibatan daerah penghasil hanya akan memperkecil bagiannya. Namun di sisi sebaliknya daerah penghasil akan berusaha untuk memperoleh jatah PI sebesar besarnya jika perlu lebih dari $10 \%$. Dan kedua kepentingan itu akan selalu berhadap-hadapan.

\section{Kesimpulan}

Pemerintah daerah melalui BUMD memiliki hak Paricipating Interest sebesar $10 \%$ terhadap kegiatan produksi migas yang dilakukan di wilayahnya. PI adalah hak untuk berpartisipasi dalam kegiatan produksi gas dengan menyetorkan modal dengan kompensasi mendapatkan bagian dari hasil bersih migas yang dihasilkan dan dibatasi dengan jangka waktu kesanggupan selama 60 hari. Pengusahaan produksi hulu Migas diharapkan memberi manfaat kepada daerah melalui keterlibatan BUMD secara langsung dalam pengusahaan sektor hulu migas dan / atau berkembangnya peluang / kegiatan usaha dan penciptaan lapangan kerja dan pendapatan di berbagai kegiatan yang terkait dengan usaha Migas.

Banyak daerah salah paham dan menganggap PI adalah hadiah dan besaran PI sebesar $10 \%$ terlalu kecil dan karenanya menuntut lebih besar. Namun dalam prakteknya kemampuan keuangan daerah sangat terbatas sehingga daerah menghadapi kesulitan untuk dapat membayar keikut sertaan (saham) dalam PI, terlebih lagi jika daerah dilarang untuk melibatkan investor. Larangan melibatkan investor swasta sesungguhnya untuk memastikan bahwa PI tersebut ditujukan khusus untuk kesejahteraan masyarakat daerah penghasil. Keterlibatkan investor swasta ditengarai juga menimbulkan akses pada timbulnya KKN dikalangan tokoh dan pimpinan daerah.

Participating Interest (PI)yang menjadi hak daerah harus dipastikan dimanfaatkan oleh daerah melalui BUMD yang sepenuhnya dimiliki oleh Daerah. Untuk itu, perlu disusun aturan perundangan yang mengatur partisipasi BUMD pada pengusahaan sektor hulu Migas, termasuk di dalamnya kewajiban kerjasama antara BUMD dengan Pertamina atau lembaga keuangan milik Negara, 
tanpa membebani BUMD dengan mengeluarkan biaya investasi dan risiko kerugian usaha. Banyak daerah diliputi kesalahah pahaman dengan anggapan PI sebagai hak tanpa kewajiban menyetorkan dana keikut sertaan.

Wilayah kerja Masela adalah Wilayah kerja baru yang memiliki kandungan gas Bumi yang cukup besar bahkan terbesar di Indonesia saat ini. Wilayah kerja ini terletak di wilayah Kabupaten Maluku Tenggara Barat di Propinsi Maluku dan berdekatan dengan propinsi NTT yang menurut rencana wilayah kerja ini akan segera berproduksi. Participating Interest (PI) dari Wilayah kerja Masela akan menghadapi kendala karena PI dibatasi dengan ketentuan jarak, 4-10 mill dari bibir pantai ke laut, sedang jarak terdekat dengan pulau Tanimbar adalah $150 \mathrm{~km}$, sehingga tidak memenuhi ketentuan syarat itu.

Jika tidak memperhatikan tujuan filosofis PI, optimalisasi Participating Interest (PI) daerah penghasil juga akan menghadapi kendala dari upaya pemerintah untuk mengoptimalkan PI yang juga dimiliki oleh PT. Pertamina (Persero) dalam rangka/ kontek kepentingan nasional Negara Kesatuan Republik Indonesia (NKRI). PI daerah penghasil juga akan berhadapan dengan kepentingan KKKS sebagaimana layaknya badan usaha yang keberadaannya bertujuan untuk mendapatkan keuntungan maksimal.

Wilayah kerja Masela harus menjadi perhatian pemerintah agar tidak salah langkah dan secara optimal dapat berlangsung secara efisien dan paling menguntungkan bagi Negara dan masyarakat setempat. Selain itu PI di wilayah kerja Masela bagi daerah penghasil yakni Propinsi Maluku dan Kabupaten Maluku Tenggara Barat harus dijaga agar tepat sasaran dan tidak menyalahi tujuan filosofisnya yakni untuk mewujudkan kesejahteraan bagi masyarakat daerah penghasil. PI wilayah kerja Masela menjadi incaran pihak swasta, oleh karenanya tugas pemerintah adalah menjaganya agar tidak jatuh kepada para pemburu rente yang tentu saja akibatnya sangat merugikan Negara dan terutama bagi daerah penghasil.

\section{Daftar Pustaka}

\section{Buku - Buku}

Agoes Soegianto, Eksplorasi dan produksi migas lepas pantai: dampak ekologis dan penanganannya,Airlangga Press, Surabaya, 2005.

A.M. Fatwa, Potret Konstitusi Pasca Amandemen UUD 1945, PT. Gramedia Media Nusantara, 2009.

A. Rianto Pudyantoro, Proyek Hulu Migas Evaluasi dan analisis Petroekonomi, Petromindo, Genta Publishing, Jakarta, 2014.

Bachrawi Sanusi,Peranan migas dalam perekonomian Indonesia, Universitas Trisakti, Jakarta, 2002.

Charlotte J. Wright and Rebecca A. Gallun, Fundamentals of Oil and Gas accounting, 5th edition, PennWell Corporation, 2008.

Deny Hidayati. dkk, Manajemen Konflik Stakeholders Delta Mahakam, Piramida Publishing berkerjasama dengan Pusat Penelitian Kependudukan, Lembaga 
Ilmu Pengetahuan Indonesia, Bandung, 2005.

Dimyati Hartono, Pola dan rencana pembangunan Negara Kesatuan Republik Indonesia (Porenbang NKRI) zaman restorasi: menuju negara maritim yang besar dan kuat di dunia,Lembaga Ekonomi Tanah Air, Jakarta, 2004.

Emil Salim, Kembali Ke Jalan Lurus, Esai-Esai 1966-99, AlvaBet, Jakarta, 2000.

Hari S. Malang Joeda, Reinventing BUMD, PT. Gramedia, 2006.

Indra Bastian, Privatisasi di Indonesia: teori dan implementasi, Salemba Empat, Jakarta, 2002.

MarwanBatubara,Tragedi \& ironi: Wilayah kerja Cepu danNasionalisme yang Tergadai,CitraKreasi Indonesia, Jakarta, 2006.

M. Amien Rais, Agenda Mendesak Bangsa Selamatkan Indonesia, PPSK Press, Yogyakarta, 2008.

M. Ryas Rasid, Otonomi Daerah: Latar Belakang dan Masa Depannya, LIPI Press, Jakarta, 2007.

Peter M. Blau, Srtuctural Contexts of Opportunities, The University of Chicago Press, Chicago, 1994.

Riant Nugroho Dwijowijoto, BUMN Indonesia: Isu, Kebijakan dan Strategi, ElexMedia Komputindo, Bandung, 2006.

Santi Dwi Desy Lestari dan Yudha Andrian Saputra, Finansial Risk Assessment Production Sharing Contrct Indonesia Kegiatan Eksploitasi Minyak Bumi Dari Perspektif Kontraktor, Institut
Teknologi Sepuluh Nopember (ITS), Surabaya, 2000.

Sumantoro,Hukum Ekonomi,Jakarta, Universitas Indonesia, 1986.

Tomi Lebang, Berbekal Seribu Akal Pemerintahan Dengan Logika, Sari pati pidato Wakil Presiden Jusuf Kalla, Gramedia Pustaka Utama, Jakarta, 2006.

\section{Jurnal/ Majalah/ Artikel}

Jurnal Analisa, Pengasilan Daerah Migas,Centre for Strategic and International Studies,Volume 6,1977

Jurnal Economics and finance in Indonesia, Universitas Indonesia, Volume 36, 1988

Jurnal Dunia Ekuin dan Perbankan, Centre for Strategic and International Studies, Volume 18,2005

Jurnal Petrominer: Petroleum, Mining \& Energy, Adijaya Cooperative, Volume 36, 2009

Jurnal Serasi, Proyek Pengembangan Informasi dan Data Kependudukan,Kantor Menteri Negara Kependudukan dan Linkungan Hidup, Potensi Sumber Dampak Pengusahaan Migas dan Panas Bumi Terhadap Lingkungan,volume 8, 1993Jurnal Economics and finance in Indonesia, Volume 36, Issue, 1988

Tim Komnas Ham, Jurnal dinamika hak asasi manusia,Universitas Surabaya. Pusat Hak Asasi Manusia, PT. Gramedia Pustaka Utama, Yayasan 
Obor Indonesia, Volume 2, 2001

Artikel Potensi dan prospek investasi di sektor pertambangan dan energi Indonesia tahun 19981999, Yayasan Krida Caraka Bhumi, 1998

\section{Undang-Undang}

Undang-Undang Dasar 1945

Undang-Undang No 22 Tahun 2001 tentang Minyak dan Gas Bumi

Undang-Undang Nomor 32 Tahun 2004 tentang Pemerintah Daerah

Undang-Undang Nomor 30 Tahun 2007 tentang Energi

Undang-Undang Nomor 33 Tahun 2004 tentang Perimbangan antara Pemerintah Pusat dan Pemerintah Daerah

Code of Federal Regulations of the United States of America, Title 17, Commodity and Securities Exchange.

Peraturan Pemerintah Nomor 35 Tahun 2004 tentang kegiatan usaha hulu minyak dan gas bumi.

\section{Internet}

http://digilib.its.ac.id/public/ITSpaper-35224-2508100149paper.pdf, diakses pada 25 Januari 2016, Pukul 20:30 WIB.

http://www.skkmigas.go.id/mengelo la-migas-untuk-kepentinganbangsa, diakses pada 25 Januari 2016, Pukul 08:00 WIB.

http://www.migas.esdm.go.id/post/c ategory/publikasi/daftarper usahaan/kontraktorkontrakk erjasama, diakses pada 25
Januari 2016, Pukul 20:00 WIB.

http://news.okezone.com/read/2015 /08/10/337/1193764/kpkdiminta-usut-dugaankorupsi-di-wilayah kerjacepu, diakses pada 24 Januari 2016, Pukul 18:00 WIB.

http://www.maduraexpose.com/per usahaan-milik-bumdsumenep-diduga-terkaitdugaan-korupsi-migas/, diakses pada 25 januari 2016, Pukul 07:30 WIB.

http://jatim.metrotvnews.com/read/ 2015/02/23/361883/perusa haan-milik-bumd-sumenepdiduga-terkait-dugaankorupsi-migas, diakses pada 25 januari 2016, Pukul 07:30 WIB.

http://www.migas.esdm.go.id/post/r ead/pemerintah-bahas-pilapangan-kepodang, diakses pada 24 Januari 2016, Pukul 07:17 WIB.

http://www.migas.esdm.go.id/post/r ead/wilayah kerja-masela-presiden-akan-panggil-inpexdan-shell, diakses pada 24 Januari 2016, Pukul 08:00 WIB.

http://www.petrominer.co.id/beritabenarkah-ada-palung-dilapangan-abadi-.html, diakses pada 24 Januari 2016, Pukul 07:00 WIB

http://ksp.go.id/wilayah kerjamasela-harus-beri-nilaitambah-perekonomiannasional\%E2\%80\%8E/, diakses pada 25 Januari 2016, Pukul 08:30 WIB.

http://www.litbang.esdm.go.id/index .php?option $=$ com_content\&vi ew $=$ article \&id $=505$ : sitesurvei-geologi-dan-geofisika- 
kelautan-di-perairan-wilayah kerja-masela-perairantanimbar-dalamkaitanpemilihan-teknik-eksploitasimigas-floating-refinery-atautransportasi-pipa-bawahlaut--\&catid=, diakses pada 24 Januari 2016, Pukul 07:30 WIB.

http://www.lemigas.esdm.go.id/id/b erita-752-10-oktober-2015rekomendasi-wilayah kerja- masela-diputuskan.html, diakses pada 24 Januari 2016, Pukul 06:20 WIB. http://industri.bisnis.com/read/201 31202/44/189979/hoa-jualbeli-gas-dari-masela-belumbisa-tahun-ini, diakses pada 25 Januari 2016, Pukul 09:00 WIB.

http://www.kabarbisnis.com/read/2 830416, diakses pada 25 Januari, Pukul 08:30 WIB. 